Western North American Naturalist 69(2), () 2009, pp. 253-256

\title{
RANGE EXPANSION OF THE COLLARED PECCARY IN NEW MEXICO: POTENTIAL FOR INTERACTIONS BETWEEN HISTORICALLY SEPARATE SUBSPECIES
}

\author{
Louis J. Lamit ${ }^{1,3}$ and Marguerite N. Hendrie ${ }^{2}$
}

\begin{abstract}
The collared peccary (Tayassu tajacu) is undergoing range expansion in the southwestern United States. Here we report sightings of the collared peccary from locations outside the known ranges of either of the subspecies, $T$. t. sonoriensis and T. t. angulatus, in south central New Mexico. Sightings include multiple individuals of different ages. This indicates that the collared peccary is expanding into previously unoccupied areas between the documented ranges of the 2 subspecies. We suggest that the possibility of gene flow between the 2 historically separate subspecies may have important evolutionary consequences.
\end{abstract}

Key words: collared peccary, Tayassu tajacu, range expansion, New Mexico, subspecies.

The collared peccary (Tayassu tajacu) is an even-toed ungulate that occupies a range of diverse habitats from central South America to the southwestern United States (Sowls 1997). It weighs approximately $18-25 \mathrm{~kg}$ at maturity and is a generalist herbivore (Theimer and Bateman 1992, Sowls 1997). Here we report collared peccary sightings by technicians (including L.J. Lamit) at the Jornada LTER (longterm ecological research) site in south central New Mexico's Dona Ana County. These sightings occurred beyond the documented range of peccaries in the state. Four observations were documented between December 2004 and February 2005 on New Mexico State University's Chihuahuan Desert Rangeland Research Center (CDRRC) near the city of Las Cruces (Fig. 1). One sighting included several individuals of various age classes, 2 included a pair of adults, and the fourth included just a single adult. In addition, numerous tracks, diggings and wallows, as well as scat were found and photographed within the same time period. In January 2006 collared peccary tracks and diggings were again seen in the vicinity of those observed in the previous year, and sightings have also occurred sporadically since 2006 (Jornada LTER technicians personal communication). Evidence and sightings of collared peccaries have occurred in years previous to 2004 on the CDRRC; however, these sighting were not adequately documented. Within the last $5-10$ years encounters have become common on the CDRRC (C. Bailey, CDRRC ranch foreman, personal communication), indicating recent range expansion into the area.

The CDRRC encompasses a plain ranging from approximately 1300 to $1400 \mathrm{~m}$ in elevation and mountains up to $1781 \mathrm{~m}$. The area has a mean annual precipitation of approximately $235 \mathrm{~mm}$, and its mean maximum ambient temperature ranges from $13.3^{\circ} \mathrm{C}$ in January to 36 ${ }^{\circ} \mathrm{C}$ in June (Gibbens et al. 2005). Documented sightings and evidence of collared peccaries on the CDRRC are from a relatively small area of approximately $15 \mathrm{~km}^{2}$ on the northeastern bajada of the Dona Ana Mountains, although their range is likely larger. Here collared peccaries primarily inhabit creosote (Larrea tridentata) shrubland and black grama (Bouteloua eriopoda) grasslands. Both signs and sightings indicate that within these habitats arroyos are common centers of activity.

Over the past 10 years, collared peccaries have also been seen on the San Andres National Wildlife Refuge (SANWR) in the San Andres Mountains (Fig. 1), the mountain range east of the CDRRC (M. Weisenberger, SANWR refuge wildlife biologist, personal communication). The San Andres Mountains range from approximately 1300 to $2700 \mathrm{~m}$ in elevation (Sweanor et at. 2000), with habitat ranging

\footnotetext{
${ }^{1}$ New Mexico State University, Department of Biology, Las Cruces, NM 88003-8001.

${ }^{2}$ Pinnacle Mapping Technologies, Inc., 601 N. Humphreys, Flagstaff, AZ 86002.

${ }^{3}$ Present address: Department of Biological Sciences, and Merriam-Powell Center for Environmental Research, Northern Arizona University, Box 5640, Flagstaff, AZ 86011-5640. E-mail: louis.lamit@nau.edu
} 


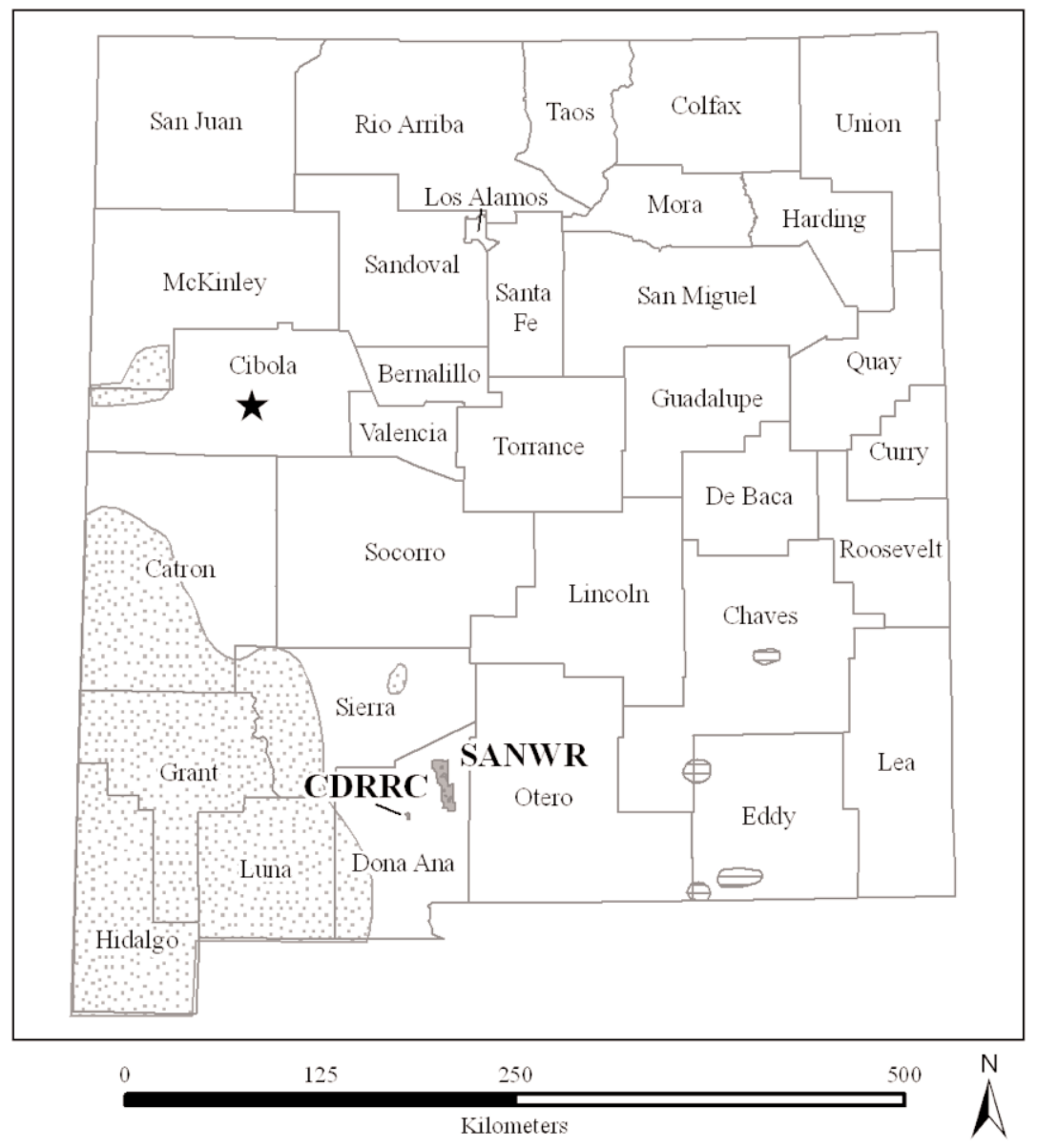

\section{Legend}

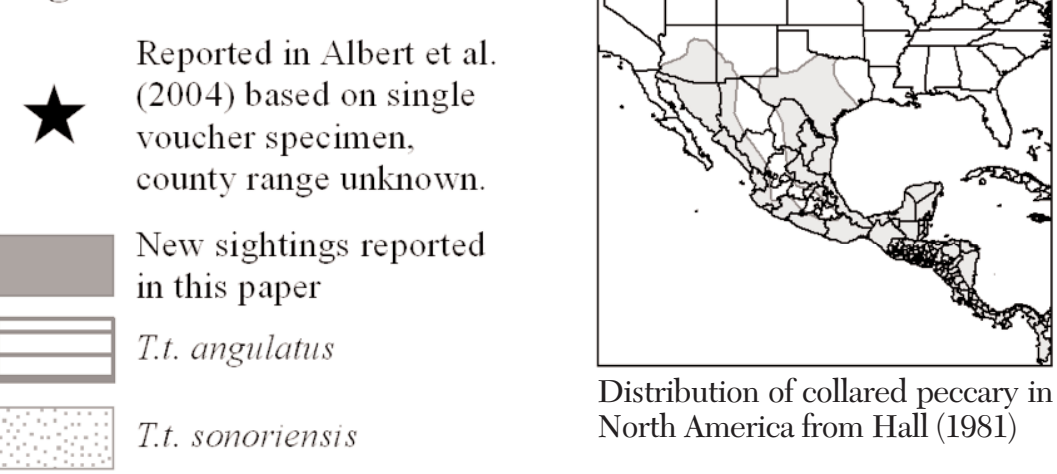

Fig. 1. Approximate documented range of collared peccary in North America and New Mexico compiled from Hall (1981), Gonzales (1986), Albert et al. (2004), and sightings reported in this article from the Chihuahuan Desert Rangeland Research Center (area of sightings highlighted) and the San Andres National Wildlife Refuge (entire refuge highlighted, specific sighting locations unknown). 
from Chihuahuan desert scrub to pinyonjuniper woodland (Dick-Peddie 1993). Gonzales (1986) discussed plans in the mid-1980s to introduce collared peccaries from Texas into the San Andres Mountains but did not mention that transplants had already occurred by that time. The New Mexico Department of Game and Fish attempted to transplant individuals to the San Andres Mountains in past decades, but these apparently did not become permanently established (M. Weisenberger personal communication 2005). This suggests the current populations may represent dispersers into the region from wild populations.

Collared peccary populations reported within this paper appear to be primarily restricted to bajadas and mountains of the Chihuahuan desert. Aside from an undocumented sighting at a nearby playa, we are unaware of sightings from the Jornada Plain, which occupies the area between SANWR in the San Andres Mountains and the CDRRC portion of the Dona Ana Mountains. This lack of sightings may correspond to the relative absence of prickly pear cacti (Opuntia spp.), an important food and water source for collared peccaries (Corn and Warren 1985, Theimer and Bateman 1992), on the plain, in contrast to higher prickly pear abundance on adjacent mountains and bajadas (L.J. Lamit personal observation). However, the plain does contain a number of perennial stock tanks, and it is impossible to rule out the presence of peccaries there because we did not conduct a thorough survey of the region. Furthermore, collared peccaries must cross plains separating higher land during dispersal events.

The collared peccary's North American range forms a $Y$ with the split in south central Mexico and the branches extending north up the entire western and eastern sides of the country (Fig. 1; Hall 1981). North of the United States-Mexico border, the collared peccary inhabits large areas of Arizona and Texas, with lower numbers in western and southeastern New Mexico. The Texas and southeastern New Mexico populations entered the region by dispersal along Mexico's eastern side and are considered part of subspecies T. t. angulatus, while the Arizona and western New Mexico populations moved north through western Mexico and are considered part of subspecies T. t. sonoriensis (Hall 1981, Theimer and Keim 1994). Tayassu t. sonoriensis extends into southwestern and west central New Mexico in Hidalgo, Grant, Luna, Catron, and Cibola counties (Fig. 1; Findley 1987, Sowls 1997, Albert et al. 2004). Albert et al. (2004) recently documented a range expansion onto the Zuni Indian Reservation in McKinley and Cibola counties of northwestern New Mexico. Some authors indicate that $T$. $t$. angulatus was extirpated in southeastern New Mexico during the previous century (Findley et al. 1975, Sowls 1997); however, T. $t$. angulatus is currently known from Otero, Chaves, Eddy, and possibly Lea counties (Fig. 1; Findley 1975, Findley 1987, Sowls 1997, Albert et al. 2004).

Historical accounts and archeological evidence suggest collared peccaries were not common in the southwestern United States a few centuries ago (Cohn 1997, Sowls 1997). Overall, the ranges of both subspecies have increased during the last several hundred years. Tayassu t. sonoriensis has shown remarkable expansion northward in Arizona and northeastward in western New Mexico (Brown 1985, Gonzales 1986, Cohn 1997, Albert et al. 2004). The map of Gonzales (1986) shows that T. $t$. sonoriensis more than doubled its range in southwestern New Mexico between 1967 and 1985. The range of T. t. angulatus also exanded in eastern New Mexico during that time but to a much smaller degree. The range of $T$. $t$. angulatus in west Texas has also been increasing (Williams 1985). Williams (1985) also noted a reduction in its eastern range in Texas due to land conversion and urbanization, although in general both subspecies do well in many urban and agricultural environments (Sowls 1997, Ticer et al. 2001). The causes of the overall range expansion are unknown. It may be due in part to transplants by game managers, but this alone does not explain the extensive degree of expansion. Sowls (1997) states that the range increases show some correlation with the encroachment of shrubs into semiarid grasslands, but more work is needed to substantiate this idea.

The subspecies of the collared peccaries reported herein is unknown. Due to the more rapid range expansion of $T$. $t$. sonoriensis than that of $T$. $t$. angulatus, and the closer proximity of the known range of $T$. $t$. sonoriensis to the new locations, it is likely that the sightings we report are of T. $t$. sonoriensis. However, if transplants to the San Andres mountains have been more successful than suspected and if the 
original animals were taken from Texas, the peccaries we report may be $T$. $t$. angulatus. In either case, the range of collared peccaries in New Mexico is expanding and may be much larger than we realize.

Lineages represented by the 2 subspecies have potentially been geographically separated for thousands of years or more (Theimer and Keim 1994). As their North American ranges increase, the subspecies may once again encounter each other and potentially interbreed. More work on the collared peccary in New Mexico is needed to determine whether this is currently happening or may happen in the near future. The first step is to determine the extent of each subspecies' expansion and if their ranges are converging. The locations of collared peccary sightings on the CDRRC are outside of the suitable but unoccupied habitat proposed by Findley et al. (1975) and Gonzales (1986), indicating that available habitat for colonization is larger than previously estimated.

Behavioral plasticity is noted as a key component for the collared peccary's survival in hot and cold arid environments (Cohn 1997, Ticer et al. 2001, Albert et al. 2004). Albert et al. (2004) suggested that its northward movement is limited by cold temperatures and that its northern range may expand and contract with variation in climate or drought conditions. Because they are on the edge of the species' range, these peripheral groups of collared peccaries may be faced with a steep selection gradient. We suggest that if genetically based behavioral or physiological traits are under selection, mating between the 2 subspecies could create novel allele combinations that may provide fitness advantages and increase the collared peccary's ability to live and expand in the southwestern United States.

We thank J.G. Kuehner and J.P. Anderson of the Jornada LTER and C. Bailey of the Department of Animal and Range Science at NMSU for details about sightings on the CDRRC. We also thank M. Weisenberger for information about sightings on the San Andres National Wildlife Refuge, and L.E. Hagenauer, T. Wojtovich, C.M. Pace, and T.C. Theimer for helpful comments on the manuscript. Documented observations reported here were made by technicians who were performing duties for the Jornada LTER, a long-term ecological research site funded by the National Science Foundation.

\section{Literature Cited}

Albert, S., C.A. Ramotnik, and C.G. Schmitt. 2004. Collared peccary range expansion in northwestern New Mexico. Southwestern Naturalist 49:524-528.

Brown, D.E., And R.A. Ockenfels. 1985. Status report on the collared peccary: Arizona. In: R.A. Ockenfels, G.I. Day, and V.C. Supplee, editors, Peccary Workshop proceedings. Phoenix: Arizona Game and Fish Department 13-18.

Conn, J.P. 1997. The peccary's progress. National Parks [July/August]:30-33.

Corn, J.L., AND R.J. Warren. 1985. Seasonal food habits of the collared peccary in south Texas. Journal of Mammalogy 66:155-159.

Dick-Peddie, W.A. 1993. New Mexico vegetation: past, present, and future. University of New Mexico Press, Albuquerque.

FindLey, J.S. 1987. The natural history of New Mexican mammals. University of New Mexico Press, Albuquerque.

Findley, J.S., A.H. Harris, D.E. Wilson, and C. Jones. 1975. Mammals of New Mexico. University of New Mexico Press, Albuquerque.

GonZales, S.R. 1986. Status report on the collared peccary: New Mexico. In: R.A. Ockenfels, G.I. Day, and V.C. Supplee, editors, Peccary Workshop proceedings. Phoenix: Arizona Game and Fish Department 13-18.

Gibbens, R.P., R.P. McNeely, K.M. Havstad, R.F. Beck, AND B. NOLEN. 2005. Vegetation changes in the Jornada Basin from 1858 to 1998. Journal of Arid Environments 61:651-668.

HaLl, E.R. 1981. The mammals of North America. 2nd edition. John Wiley \& Sons, New York.

SowLS, L.K. 1997. Javelinas and other peccaries: their biology, management, and use. 2nd edition. Texas A\&M University Press, College Station.

Sweanor, L.A., K.A. Logan, AND M.G. Hornocker. 2000. Cougar dispersal patterns, metapopulation dynamics and conservation. Conservation Biology 14:798-808.

Theimer, T.C., and G.C. Bateman. 1992. Patterns of prickly-pear herbivory by collared peccaries. Journal of Wildlife Management 56:234-240.

Theimer, T.C., AND P. KeIM. 1994. Geographic patterns of mitochondrial-DNA variation in collared peccaries. Journal of Mammalogy 75:121-128.

Ticer, C.L., T.E. Morrell, and J.C. Devos, Jr. 2001. Diurnal bed-site selection of urban dwelling javelina in Prescott, Arizona. Journal of Wildlife Management 65:136-140.

WILLIAMS, W.J. 1985. Status report on the collared peccary: Texas. In: R.A. Ockenfels, G.I. Day, and V.C. Supplee, editors, Peccary Workshop proceedings. Phoenix: Arizona Game and Fish Department 13-18.

Received 12 May 2008

Accepted 3 October 2008 